\title{
Hemodynamic and antiarrhythmic effects of lidocaine or amiodarone in dogs anesthetized with halothane
}

\author{
[Efeitos hemodinâmicos e antiarrítmicos da lidocaína ou amiodarona em cães \\ anestesiados com halotano] \\ J.V. Moro ${ }^{1}$, N. Nunes ${ }^{2 *}$, V.F. Barbosa ${ }^{1}$, R. Thiesen ${ }^{1}$, P.C.F. Lopes ${ }^{3}$, E.A. Belmonte ${ }^{1}$, \\ P.A. Borges ${ }^{1}$, P.A.C.S. Batista ${ }^{1}$, P.F. Costa ${ }^{1}$ \\ ${ }^{1}$ Aluna (o) de pós-graduação - Faculdade de Ciências Agrárias e Veterinárias (FCAV-Unesp) - Jaboticabal, SP \\ ${ }^{2}$ Faculdade de Ciências Agrárias e Veterinárias - (FCAV-Unesp) - Jaboticabal, SP \\ ${ }^{3}$ Pós-doutoranda - Faculdade de Ciências Agrárias e Veterinárias (FCAV-Unesp) - Jaboticabal, SP
}

\begin{abstract}
The effects of continuous rate infusion of lidocaine or amiodarone on hemodynamic and arrhythmias induced by epinephrine in dogs anesthetized with halothane were evaluated. Thirty dogs were distributed into three groups: amiodarone group (AG), lidocaine group (LG), or control group (CG). Anesthesia was induced with etomidate and maintained with halothane. Thirty minutes later a bolus and continuous rate infusion (CRI) of amiodarone in $\mathrm{AG}$, lidocaine in $\mathrm{LG}$ and $\mathrm{NaCl}$ at $0.9 \%$ in $\mathrm{CG}$ was administered. After 10 minutes, arrhythmias were induced by epinephrine CRI at $0.0001 \mathrm{mg} / \mathrm{kg} /$ minute, which was increased in $0.0001 \mathrm{mg} / \mathrm{kg} /$ minute every ten minutes, until $0.0003 \mathrm{mg} / \mathrm{kg} / \mathrm{minute}$. The measurements were performed 30 minutes after the induction of anesthesia (T0), 10 minutes after beginning the drug CRIs (T1), 10 minutes after beginning epinephrine administration (T2) and 10 minutes after increasing epinephrine CRI (T3 and T4). In CG, at T3 heart rate (HR) was greater than in LG, while at T4, HR in GC was higher than in LG and AG. In LG and CG, from T2, central venous pressure (CVP), cardiac index (CI), systolic arterial pressure (SAP), diastolic arterial pressure (DAP), mean arterial pressure (MAP), mean pulmonary arterial pressure (mPAP) increased. In AG, SAP, DAP and MAP it decreased from T1 to T3. The ventricular ectopic beats (VEB) were lower in AG. Amiodarone has better antiarrhythmogenic effects, although it was also associated with hypotension.
\end{abstract}

Keywords: canine, antiarrhythmogenicity, anesthesia

\section{RESUMO}

Avaliaram-se os efeitos da infusão contínua de lidocaína ou amiodarona sobre a hemodinâmica e as arritmias induzidas pela epinefrina em cães anestesiados com halotano. Trinta animais foram distribuídos em três grupos: grupo amiodarona (GA), grupo lidocaína $(G L)$ ou grupo-controle $(G C)$. A anestesia foi induzida com etomidato e mantida com halotano. Trinta minutos após, foram administrados bolus e infusão contínua (CRI) de amiodarona no GA, de lidocaína no GL e de $\mathrm{NaCl}$ a 0,9\% no GC. Após 10 minutos, iniciou-se a CRI de epinefrina $(0,0001 \mathrm{mg} / \mathrm{kg} /$ minuto $)$, aumentando-se $0,0001 \mathrm{mg} / \mathrm{kg} /$ minuto a cada 10 minutos até 0,0003mg/kg/minuto. As mensurações foram realizadas 30 minutos após a indução anestésica (T0), 10 minutos após a CRI dos fármacos (T1), 10 minutos após a administração de epinefrina (T2) e a cada 10 minutos após o incremento na CRI de epinefrina (T3 e T4). A frequência cardíaca (FC) foi maior no GC que no GL em T3 e maior em GC que nos demais grupos em T4. A partir de T2, houve aumento na pressão venosa central (PVC), no índice cardíaco (IC), nas pressões arteriais sistólica (PAS), diastólica (PAD) e média (PAM) e na pressão média da artéria pulmonar (PAPm) no GL e no GC. No GA, PAS, PAD e PAM diminuíram de T1 a T3. Os batimentos ventriculares ectópicos (BVE) foram menores no GA. Amiodarona possui melhores efeitos antiarrítmicos, apesar de também estar associada com hipotensão.

Palavras-chave: cães, antiarritmogenicidade, anestesia

Recebido em 1 de março de 2012

Aceito em 6 de março de 2013

*Autor para correspondência (corresponding author)

E-mail: newton@fcav.unesp.br 


\section{INTRODUCTION}

Cardiac arrhythmias are frequent complications during surgical/anesthetic procedures. Myocardial sensitization to endogenous and exogenous catecholamines, caused by anesthetic halogenated agents, can contribute to the appearance of arrhythmias (Harvey and Ettinger, 2007).

Lidocaine, a drug that has antiarrhythmic potential through a sodium-channel blockade, has been used in patients who are refractory to electrical cardioversion of ventricular fibrillation (An et al., 1996). However, amiodarone, which blocks the potassium channels preferentially, is responsible for a higher survival rate in comparison to lidocaine. In patients after cardiac arrest, intravenous amiodarone is better than other antiarrhythmic drugs, because it is more efficient and produces less proarrhythmic effects (Dorian et al., 2002; Oliveira et al., 2005). Moreover, amiodarone has been reported to be effective in the treatment of many refractory arrhythmias to other antiarrhythmic drugs, and it has been used as a first choice in the treatment of supraventricular and ventricular arrhythmias (Gillis and Kates, 1984; Desai et al., 1997).

Experimental dog models have been widely used to study atrial and ventricular arrhythmia mechanisms in vivo and the effects of antiarrhythmic and proarrhythmic drugs (Noda and Hashimoto, 2004). In this study we used the combination of halothane with epinephrine as an experimental model for the induction of arrhythmias, because although this drug is rarely used as a routine, it is the halogen that causes the greater myocardial sensitization to catecholamines (Harvey and Ettinger, 2007). Therefore, this study was designed to assess the effects of continuous rate infusion of lidocaine or amiodarone on hemodynamic and arrhythmias induced by epinephrine in dogs anesthetized with halothane.

\section{MATERIAL AND METHODS}

This study was approved by the Institutional Ethics and Animal Welfare Committee (protocol $\mathrm{n}^{\circ}$ 017627-05). After the experiment, the animals were offered for adoption.

Thirty adult mongrel dogs, fifteen males and fifteen females, weighing $10.3 \pm 3.7 \mathrm{~kg}$, were enrolled in the study. All animals were determined to be healthy based on a complete physical examination, blood cell count (CBC), standard serum biochemistry test, thoracic radiograph and electrocardiogram.

The animals were acquired from a kennel of research dogs and 20 days before the procedure they were kept in individual cages at the Veterinary Hospital to allow acclimatization. The dogs were provided with regular dog food (Pedigree ${ }^{\circledR}$ adulto carne \& marrowbone, Mars Brasil, Mogi Mirim, SP, Brazil) twice a day and water ad libitum. Food, but not water, was withheld for 12 hours prior to the experiment.

The dogs were randomly assigned to three groups: control group (CG), lidocaine group (LG) and amiodarone group (AG). Anesthesia was induced with $5 \mathrm{mg} / \mathrm{kg}$ of etomidate IV (Etomidato, Cristália, Itapira, SP, Brazil) (Paula et al., 2010). After intubation, halothane (Tanohalo, Cristália, Itapira, SP, Brazil) at a concentration of $1.3 \pm 0.1 \mathrm{~V} \%$ in $100 \%$ of oxygen at a flow rate of $30 \mathrm{~mL} / \mathrm{kg}^{\prime}$ minute, using a re-breathing anesthetic circuit with partial rebreathing of gases (Ohmeda - Excel 210SE, Madison, EUA - Proc. FAPESP 97/10668-4) and equipped with a calibrated vaporizer (OHMEDA model Fluotec 4, Datex Ohmeda, Miami, EUA Proc. FAPESP 97/10668-4) was used.

The dogs were positioned in dorsal recumbency on a heating pad (T/pump Localized Heat Therapy System - Model Tpp522; Gaymar Industries, Inc., NY, USA) and body temperature was maintained at $37.7 \pm 0.8^{\circ} \mathrm{C}$ during the whole study. A teflon catheter (Catheter BD Angiocath 22, Becton, Dickinson Indústria Cirúrgica Ltda, Juiz de Fora, MG, Brazil) was placed percutaneously in the left cephalic vein and another in the left saphenous vein for drug administration.

Next, rocuronium IV (Esmeron, Organon, São Paulo, SP, Brazil) was administered $(0.6 \mathrm{mg} / \mathrm{kg})$ followed by a continuous rate infusion (CRI) $(0.6 \mathrm{mg} / \mathrm{kg} / \mathrm{h})$ using an infusion pump (Bomba de seringa AS50, Samtronic, São Paulo, SP, Brazil). Controlled ventilation began immediately, and the respiratory rate and tidal volume with a maximum inspiratory pressure of $20 \mathrm{~cm} \mathrm{H}_{2} \mathrm{O}$ were adjusted, with the use of a multiparametric monitor (DX 2010LCD, Dixtal, Manaus, AM, Brazil - Proc. FAPESP 02/04625-0), to achieve an end-tidal partial pressure of carbon dioxide $\left(\mathrm{PE}^{\prime} \mathrm{CO}_{2}\right)$ of 35 to $45 \mathrm{mmHg}(4.7-6 \mathrm{kPa})$. These settings were not changed during the remainder of the study. 
A 22-gauge intra-arterial catheter (Catheter BD Angiocath 22, Becton, Dickinson Indústria Cirúrgica Ltda, Juiz de Fora, MG, Brazil) was placed in the right tarsal artery to assess systolic (SAP), diastolic (DAP) and mean arterial pressure (MAP) using a multiparametric monitor (Dixtal mod. DX 2010, Invasive AP module, Brazil - Proc. FAPESP 02/04625-0). Before the beginning of each experiment, the pressure transducer was checked against a mercury manometer. The zero reference point was at the level of the costochondral junction.

An introducer (Catheter BD Insyte 14; Becton, Dickinson Indústria Cirúrgica Ltda) was placed in the jugular vein, and, through it, a Swan-Ganz catheter (Catheter 132 - 5F; Edwards Lifesciences LLC, CA, USA) was fed to the lumen of the pulmonary artery. The correct positioning of the catheter in the pulmonary artery was verified by observation of the characteristic pressure waveforms. $\mathrm{CO}$ was measured indirectly by a thermodilution technique using a microprocessor device (Dixtal mod. DX 2010, CO module, Brazil - Proc. FAPESP 02/04625-0). The computer constant was set for a 5-F Swan-Ganz catheter, an injection temperature from 0 to $5^{\circ} \mathrm{C}$ and an injection volume of $3 \mathrm{~mL}$. Each measurement was made after the administration of $3 \mathrm{~mL}$ of cold $\left(0-3^{\circ} \mathrm{C}\right) 3 \mathrm{~mL} 0.9 \%$ sodium chloride over $<3$ seconds, three times. The injections were done by hand, by only one person and the mean of these three measurements was used if the values were within $10 \%$ of each other. Central venous pressure (CVP), body temperature (BT) and mean pulmonary arterial pressure (mPAP) were measured via the thermodilution catheter.

Thirty minutes after the induction of anesthesia, a bolus followed by a continuous rate infusion (CRI) of amiodarone (Ancoron, Libbs Farmacêutica, São Paulo, SP, Brazil) in AG $(5 \mathrm{mg} / \mathrm{kg}$ and $0.17 \mathrm{mg} / \mathrm{kg} / \mathrm{minute})$, of lidocaine (Xylestesin, Cristália, Itapira, SP, Brazil) in LG $(1 \mathrm{mg} / \mathrm{kg}$ and $0.075 \mathrm{mg} / \mathrm{kg} /$ minute $)$ and $\mathrm{NaCl}$ at $0.9 \%$ in CG $(1 \mathrm{~mL}$ and $5 \mathrm{~mL} /$ hour $)$ was administered. Amiodarone and lidocaine were diluted in $\mathrm{NaCL}$ at $0.9 \%$ to obtain a rate of $5 \mathrm{~mL} /$ hour. The solution was administered using a syringe infusion pump (Bomba de seringa ST 680, Samtronic, São Paulo, SP, Brazil).
Ten minutes after the beginning of CRI of lidocaine, amiodarone, or the $\mathrm{NaCl}$ at $0.9 \%$, an infusion of epinephrine (Drenalin, Ariston, São Paulo, SP, Brazil) was started at $0.0001 \mathrm{mg} / \mathrm{kg} / \mathrm{min}$, using a peristaltic infusion pump (Bomba de infusão FARS 600, Lifemed, São Paulo, SP, Brazil). The rate was increased in $0.0001 \mathrm{mg} / \mathrm{kg} / \mathrm{min}$ each ten minutes, until $0.0003 \mathrm{mg} / \mathrm{kg} / \mathrm{min}$. Epinephrine was diluted in $\mathrm{NaCl}$ at $0.9 \%$, using a $0.002 \%$ solution for continuous rate infusion.

Heart rate (HR) was measured using a computerized electrocardiograph (TEB, mod. ECGPC software version 1.10, Brazil) adjusted to lead II. Ventricular ectopic beats (VEB) were also obtained by computerized electrocardiograph. The VEB measured were the average of the 10-minute evaluation period. Cardiac index (CI), in $\mathrm{L}$ minute $\mathrm{m}^{-2}$, was calculated using the following formula:

$\mathrm{CI}=\mathrm{CO} / \mathrm{BSA}$, where BSA $($ body surface area $)=$ weight ${ }^{0.6667} / 10$;

The measurements of parameters were performed 30 minutes after the induction of anesthesia (T0), 10 minutes after the beginning of the continuous rate infusion of drugs (T1), 10 minutes after the beginning of epinephrine administration (T2) and 10 minutes after increasing the epinephrine continuous rate infusion (T3 and T4)

After the normality and homoscedasticity tests were performed, numeric data were submitted to variance analysis (ANOVA) followed by a Tukey test $(p<0.05)$. The ventricular ectopic beats data was subjected to the Kruskal-Wallis non-parametric statistical method $(\mathrm{P}<0.05)$. Analyses were performed using Sigma Stat software (Sigma Stat for Windows - Systat Software Inc., San Jose, CA, USA).

\section{RESULTS}

For heart rate, at $\mathrm{T} 3$, the control group has greater value than the lidocaine group and at T4, LG and amiodarona groups had lower means than CG. In CG, at T4, the HR value was greater than other times. At $\mathrm{T} 1$ and $\mathrm{T} 2$, heart rate was lower than at T3 and T4 (Table 1). 
Hemodynamic and antiarrhythmic...

Table 1. Hemodynamics parameters and ventricular ectopic beats during continuous rate infusion of $\mathrm{NaCl}$ at $0.9 \%(\mathrm{CG})$, lidocaine (LG) and amiodarone (AG) in halothane-anesthetized dogs induced to arrhythmias by epinephrine

\begin{tabular}{|c|c|c|c|c|c|c|}
\hline \multirow{2}{*}{ Parameter } & & \multicolumn{5}{|c|}{ Times } \\
\hline & & T0 & $\mathrm{T} 1$ & $\mathrm{~T} 2$ & T3 & $\mathrm{T} 4$ \\
\hline \multirow{3}{*}{$\begin{array}{c}\text { HR } \\
\text { (beat minute }^{-1} \text { ) }\end{array}$} & $\mathrm{CG}$ & $78 \pm 10 \mathrm{ab}$ & $76 \pm 12 b$ & $77 \pm 17 b$ & $100 \pm 25 \mathrm{Aa}$ & $123 \pm 50 \mathrm{Ac}$ \\
\hline & LG & $74 \pm 21$ & $73 \pm 22$ & $66 \pm 15$ & $71 \pm 18 B$ & $83 \pm 16 B$ \\
\hline & $\mathrm{AG}$ & $82 \pm 16$ & $83 \pm 18$ & $81 \pm 15$ & $86 \pm 25 \mathrm{AB}$ & $92 \pm 21 B$ \\
\hline \multirow{3}{*}{$\begin{array}{c}\mathrm{VEB}^{*} \\
\text { (beat minute }^{-1} \text { ) }\end{array}$} & $\mathrm{CG}$ & $0 \mathrm{a}$ & $0 \mathrm{a}$ & $37 \pm 45 \mathrm{Ab}$ & $42 \pm 8 \mathrm{ab}$ & $150 \pm 243 \mathrm{Ab}$ \\
\hline & LG & $0 \mathrm{a}$ & $0 \mathrm{a}$ & $30 \pm 61 \mathrm{ABb}$ & $30 \pm 39 b$ & $44 \pm 92 \mathrm{ABb}$ \\
\hline & $\mathrm{AG}$ & 0 & 0 & $1 \pm 2 B$ & $5 \pm 15$ & OB \\
\hline \multirow{3}{*}{$\begin{array}{c}\text { CVP } \\
(\mathrm{mmHg})\end{array}$} & $\mathrm{CG}$ & $8 \pm 3 a$ & $7 \pm 2 a$ & $14 \pm 5 \mathrm{Ab}$ & $16 \pm 5 \mathrm{Ab}$ & $15 \pm 6 \mathrm{Ab}$ \\
\hline & LG & $5 \pm 3 a$ & $5 \pm 3 a$ & $11 \pm 3 \mathrm{Ab}$ & $12 \pm 3 \mathrm{Bb}$ & $11 \pm 4 \mathrm{Bb}$ \\
\hline & $\mathrm{AG}$ & $4 \pm 3$ & $3 \pm 3$ & $4 \pm 3 B$ & $5 \pm 3 C$ & $5 \pm 4 C$ \\
\hline \multirow{3}{*}{$\begin{array}{c}\text { CI } \\
\left(\mathrm{L} \text { minute }{ }^{-1} \mathrm{~m}^{-2}\right)\end{array}$} & $\mathrm{CG}$ & $2,8 \pm 1,2 \mathrm{a}$ & $3,0 \pm 1,2 \mathrm{Aa}$ & $3,5 \pm 0,9 \mathrm{Aab}$ & $3,9 \pm 0,9 \mathrm{Ab}$ & $4,1 \pm 0,6 \mathrm{Ab}$ \\
\hline & LG & $2,9 \pm 0,3 \mathrm{a}$ & $3,1 \pm 0,3 \mathrm{Aab}$ & $3,7 \pm 0,6 \mathrm{Abc}$ & $4,0 \pm 0,7 \mathrm{Ac}$ & $4,2 \pm 0,7 \mathrm{Ac}$ \\
\hline & $\mathrm{AG}$ & $2,3 \pm 0,6 \mathrm{ac}$ & $1,1 \pm 0,3 \mathrm{Bb}$ & $1,8 \pm 0,7 \mathrm{Bab}$ & $2,5 \pm 1,1 \mathrm{Bac}$ & $2,8 \pm 1,2 \mathrm{Bc}$ \\
\hline \multirow{3}{*}{$\begin{array}{c}\mathrm{SAP} \\
(\mathrm{mmHg})\end{array}$} & $\mathrm{CG}$ & $104 \pm 28 \mathrm{a}$ & $105 \pm 17 \mathrm{Aa}$ & $186 \pm 53 \mathrm{Ab}$ & $217 \pm 46 \mathrm{Ab}$ & $205 \pm 41 \mathrm{Ab}$ \\
\hline & LG & $116 \pm 19 a$ & $113 \pm 19 \mathrm{Aa}$ & $179 \pm 51 \mathrm{Ab}$ & $215 \pm 33 \mathrm{Ac}$ & $237 \pm 35 \mathrm{Ac}$ \\
\hline & $\mathrm{AG}$ & $96 \pm 20 a$ & $40 \pm 11 \mathrm{Bb}$ & $63 \pm 31 \mathrm{Bbc}$ & $89 \pm 39 \mathrm{Bac}$ & $105 \pm 42 \mathrm{Ba}$ \\
\hline \multirow{3}{*}{$\begin{array}{c}\text { DAP } \\
(\mathrm{mmHg})\end{array}$} & $\mathrm{CG}$ & $53 \pm 11 a$ & $55 \pm 10 \mathrm{Aa}$ & $106 \pm 47 \mathrm{Ab}$ & $130 \pm 42 \mathrm{Ab}$ & $125 \pm 41 \mathrm{Ab}$ \\
\hline & LG & $63 \pm 14 a$ & $63 \pm 14 \mathrm{Aa}$ & $111 \pm 29 \mathrm{Ab}$ & $126 \pm 24 \mathrm{Abc}$ & $144 \pm 32 \mathrm{Ac}$ \\
\hline & $\mathrm{AG}$ & $52 \pm 16 a$ & $24 \pm 5 \mathrm{Bb}$ & $33 \pm 13 \mathrm{Bab}$ & $45 \pm 16 \mathrm{Bab}$ & $55 \pm 19 \mathrm{Ba}$ \\
\hline \multirow{3}{*}{$\begin{array}{c}\text { MAP } \\
(\mathrm{mmHg})\end{array}$} & $\mathrm{CG}$ & $69 \pm 16 a$ & $70 \pm 13 \mathrm{Aa}$ & $135 \pm 46 \mathrm{Ab}$ & $162 \pm 41 \mathrm{Ac}$ & $154 \pm 38$ Ac \\
\hline & LG & $76 \pm 21 a$ & $79 \pm 15 \mathrm{Aa}$ & $134 \pm 35 \mathrm{Ab}$ & $153 \pm 24 \mathrm{Abc}$ & $173 \pm 21 \mathrm{Ac}$ \\
\hline & $\mathrm{AG}$ & $66 \pm 18 \mathrm{ac}$ & $29 \pm 6 B b$ & $44 \pm 19 \mathrm{Bbc}$ & $60 \pm 23 \mathrm{Bac}$ & $72 \pm 26 \mathrm{Ba}$ \\
\hline \multirow{3}{*}{$\begin{array}{c}\text { mPAP } \\
(\mathrm{mmHg})\end{array}$} & $\mathrm{CG}$ & $14 \pm 5 a$ & $15 \pm 3 a$ & $25 \pm 6 \mathrm{Ab}$ & $26 \pm 16 \mathrm{Ab}$ & $36 \pm 12 \mathrm{Ac}$ \\
\hline & $\mathrm{LG}$ & $12 \pm 4 a$ & $12 \pm 3 a$ & $20 \pm 6 \mathrm{Ab}$ & $22 \pm 5 \mathrm{Ab}$ & $25 \pm 6 \mathrm{Bb}$ \\
\hline & $\mathrm{AG}$ & $9 \pm 3 a$ & $10 \pm 4 a$ & $13 \pm 2 \mathrm{Bab}$ & $15 \pm 3 \mathrm{Bab}$ & $17 \pm 5 \mathrm{Cb}$ \\
\hline
\end{tabular}

Means with different low case letters within each row differ significantly from one another using the Tukey Test (p<0.05). Means with different letters within each column differ significantly from one another using the Tukey Test $(\mathrm{p}<0.05)$.

*Data (VEB) submitted to the Kruskal-Wallis non-parametric statistical method $(\mathrm{P}<0.05)$.

HR - heart rate; VEB - ventricular ectopic beats; CVP - central venous pressure; CI - cardiac index; SAP - systolic arterial pressure; DAP - diastolic arterial pressure; MAP - mean arterial pressure; mPAP - mean pulmonary arterial pressure.

T0: 30 minutes after the induction of anesthesia, T1: 10 minutes after the beginning of drug CRIs, T2: 10 minutes after the beginning of epinephrine administration, T3: 10 minutes after the first epinephrine CRI increase, T4: 10 minutes after the second epinephrine CRI increase.

In AG, at $\mathrm{T} 2$ and $\mathrm{T} 4$, ventricular ectopic beats were lower than in CG (Table 1). In CG and LG, the ventricular ectopic beats occurred when the continuous rate infusion of epinephrine increase began.

From $\mathrm{T} 1$ on, in $\mathrm{AG}$, the cardiac index means were lower than the values in the other groups (Table 1). In CG and LG, at T3 and T4, the CI values were greater than those recorded at $\mathrm{T} 0$ and $\mathrm{T} 1$. In AG, at T0, cardiac index was greater than at $\mathrm{T} 1$, which was lower than at $\mathrm{T} 4$ and $\mathrm{T} 3$. At T4, CI was greater than at T2.

The systolic, diastolic and mean arterial pressure values were lower in the amiodarone group compared to the control group and the lidocaine group (Table 1). In CG, SAP and DAP increased from T2 on. For MAP, at T4, T3 and T2 the values were greater than means at $\mathrm{T} 0$ and $\mathrm{T} 1$, but values at $\mathrm{T} 2$ were lower than means at $\mathrm{T} 4$ and $\mathrm{T} 3$. In the lidocaine group, at $\mathrm{T} 0$ and $\mathrm{T} 1$, systolic arterial pressure was lower than at $\mathrm{T} 2, \mathrm{~T} 3$ and T4. At T2 SAP was lower than at T3 and T4. For diastolic and mean arterial pressure, at T0 and $\mathrm{T} 1$, values were lower than at $\mathrm{T} 2, \mathrm{~T} 3$ and $\mathrm{T} 4$, which was greater than at T2. In the amiodarone group, at T1 and T2, SAP and MAP were lower than at $\mathrm{T} 0$ and $\mathrm{T} 4$, while at $\mathrm{T} 3$ the mean was greater than at T1. At T1, the DAP values were lower than at $\mathrm{T} 0$ and $\mathrm{T} 4$.

Central venous pressure was lower in the amiodarone group than compared with control 
and lidocaine groups at $\mathrm{T} 2, \mathrm{~T} 3$ and $\mathrm{T} 4$. In LG, central venous pressure was lower than in $\mathrm{CG}$ at $\mathrm{T} 3$ and T4. In the control and lidocaine groups, CVP increased from $\mathrm{T} 2$ on. In $\mathrm{AG}$, no differences among times were observed for central venous pressure (Table 1).

The mean pulmonary arterial pressure values in amiodarona group were lower than in control and lidocaine groups at T2, T3 and T4. At T4, the mean pulmonary arterial pressure in $\mathrm{CG}$ was greater than in LG. In CG and LG, mPAP increased from $\mathrm{T} 2$ on. In $\mathrm{AG}$, at $\mathrm{T} 4$, the mean pulmonary arterial pressure was greater than the other times (Table 1).

\section{DISCUSSION}

Although the intravenous administration of amiodarone can cause bradycardia and atrioventricular blockades, which are related to non-competitive $\beta$-adrenergic blockades (Balser, 1997), in this study no heart rate decrease was observed. This event can be explained by the vasodilator action of this drug, which resulted in a sympathetic response that reduces the decrease in heart rate (Balser 1997; Desai et al., 1997).

Additionally, in the amiodarone group, epinephrine did not increase heart rate, probably due to the amiodarone, and showed marked but partial antagonistic effects on various $\alpha$ and $\beta$ adrenergic cardiovascular phenomena, such as hypertension and tachycardia induced by noradrenaline and adrenaline (Côté et al., 1979). In LG, HR did not change, because lidocaine and conduction velocity decrease automatically (Collinsworth et al., 1974). The HR increase, which was expected after continuous infusion of epinephrine administration, was attenuated in this study by the continuous rate infusion of lidocaine.

In this study, the continuous rate infusion of lidocaine did not decrease the number of ventricular ectopic beats, when compared with the continuous rate infusion of $\mathrm{NaCl}$ at $0.9 \%$. This event corroborates Kitaa and Mitema (1994), who observed that the previous treatment with lidocaine was not able to abolish the appearance of ventricular ectopic beats in halothane-anesthetized dogs and submitted to adrenaline. The lidocaine failed to reverse the depressant effect of halothane in atrioventricular conduction. This may explain lidocaine ineffectiveness in treating certain types of arrhythmias during halothane anesthesia (Atlee et al., 1975). In AG, the number of ventricular ectopic beats was lower, which demonstrated that amiodarone inhibited the development of conduction disturbance induced by halothane and epinephrine association. Thus we believe that amiodarone has greater antiarrhytmiogenic effect than lidocaine, corroborating other manuscripts that show that amiodarone is more effective in preventing this kind of arrhythmia than other drugs that have calcium and sodium channel blocking activity (Takada et al., 1993).

Whereas lidocaine does not interfere in systemic arterial pressure (Lunney and Ettinger, 1995), the increase of arterial pressure in LG, from T2 on, was due to the greater sympathetic activity and a higher concentration of catecholamine in blood circulation (Schröeter and Rogers, 2000). In AG, there was hypotension (MAP $<60 \mathrm{mmHg}$ ) after starting continuous rate infusion of amiodarone. This event can be justified by the vasodilator and negative inotropic effects of amiodarone and its diluent (polysorbate 80). These effects are the result of a noncompetitive blockade at $\alpha$ and $\beta$-adrenoreceptor, respectively (Balser, 1997). There is evidence that, in dogs, a polysorbate 80 diluent is the main agent of severe hypotension induced by commercial amiodarone. Thus, this drug's risks should be taken into account during halothane anesthesia (Gough et al., 1982).

In the lidocaine and control groups, the higher cardiac index was due to continuous rate infusion of epinephrine which promoted an increase in cardiac output, which arises largely from the positive inotropic and chronotropic actions of the heart, but there may be vascular factors (Aviado $\mathrm{Jr}$, 1959). In this study the cardiac index decreased after the infusion of amiodarone. However, studies have shown that this drug generally maintains (Podrid, 1995) or increases the cardiac index (Desai et al., 1997). We believe that this event can be justified by the association of amiodarone and halothane, which amplifies the depressing effects on cardiac automaticity, atrioventricular conduction, and hemodynamics (Rooney et al., 1991). According to Rooney et al. (1991), amiodarone and halothane produce additive cardiac depressant effects. 
The infusion of epinephrine promoted central venous pressure increase in LG and CG, because this drug has a peripheral vasoconstrictor action (Aviado Jr, 1959), which promotes greater peripheral resistance and consequent increases in afterload and preload. However, this epinephrine effect was not observed in AG, most likely due to the vasodilation effect of amiodarone and antiadrenergic action, which caused preload drop and might have attenuated the epinephrine's vasoconstriction (Mugelli, 2001).

The mean pulmonary arterial pressure values increased in LG and CG from T2 on due to the continuous rate infusion of epinephrine (Cheung and Barrington, 2001). According to Moraes et al. (1998), the decrease in cardiac contractility, caused by lidocaine, can influence mean pulmonary arterial pressure and central venous pressure increases, due to the high pressure of the left ventricular filling. In the amiodarone group, mean pulmonary arterial pressure increased only after the third infusion of epinephrine, suggesting that the adrenergic action of amiodarone had attenuated vasoconstriction caused by epinephrine.

\section{CONCLUSION}

Although amiodarone has better antiarrhythmogenic effects when compared to lidocaine, this drug was also associated with hypotension in halothane-anesthetized dogs induced to arrhythmias by epinephrine.

\section{ACKNOWLEDGEMENTS}

The authors would like to thank the Fundação de Amparo à Pesquisa do Estado de São Paulo FAPESP, for the financial support and scholarships.

\section{REFERENCES}

AN, R.H.; BANGALORE, R.; ROSERO, S.Z. et al. Lidocaine block of LQT-3 mutant human $\mathrm{Na}^{+}$ channels. Circ. Res., v.79, p.103-108, 1996.

ATLEE, J.L.; HOMER, L.D.; TOBEY, R.E. Diphenylhydantoin and lidocaine modification of A-V conduction in halothane-anesthetized dogs. Anesthesiology, v.43, p.49-60, 1975.
AVIADO JR, D.M. Cardiovascular effects of some commonly used pressor amines. Anesthesiology, v.20, p.71-97, 1959.

BALSER, J.R. The rational use of intravenous amiodarone in the perioperative period. Anesthesiology, v.86, p.974-987, 1997.

CHEUNG, P.; BARRINGTON, K.J. The effects of dopamine and epinephrine on hemodynamics and oxygen metabolism in hypoxic anesthetized piglets. Crit. Care, v.5, p.158-166, 2001.

COLLINSWORTH, K.A.; KALMAN, S.M.; HARRISON, D.C. The clinical pharmacology of lidocaine as an antiarrhythymic drug. Circulation, v.50, p.1217-1230, 1974.

CÔTÉ. P.; BOURASSA, M.G.; DELAYE, J. et al. Effects of amiodarone on cardiac and coronary hemodynamics and on myocardial metabolism in patients with coronary artery disease. Circulation, v.59, p.1165-1172, 1979.

DESAI, A.D.; CHUN, S.; SUNG, R.J. The role of intravenous amiodarone in the management of cardiac arrhythmias. Ann. Int. Med., v.127, p.294-303, 1997.

DORIAN, P.; CASS, D.; SCHWARTZ, B. et al. Amiodarone as compared with lidocaine for shock-resistant ventricular fibrillation. New Eng. J. Med., v.346, p.884-890, 2002.

GILLIS, A.M.; KATES, R.E. Clinical pharmacokinetics of the newer antiarrhythmic agents. Clin. Pharmacokinet., v.9, p.375-403, 1984.

GOUGH, W.B.; ZELLER, R.H.; BARRECA, P. et al. Hypotensive action of commercial intravenous amiodarone and polysorbate 80 in dogs. J. Cardiov. Pharmacol., v.4, p.375-380, 1982.

HARVEY, R.C.; ETTINGER, S.J. Cardiovascular disease. In: TRANQUILLI, W.J.; THURMON, J.C.; GRIMM, K.A. (Ed). Lumb \& Jones' veterinary anesthesia. 4.ed. UK: Blackwell Publishing, 2007. p.891-897.

KITAA, J.M.A.; MITEMA, E.S. Effects of antiarrhythmic drugs (verapamil, propanolol and lignocaine) on the eletrocardiogram and haematology in adrenaline-induced arrhythmias in dogs anaesthetized with halothane. Brit. Vet. J., v.50, p.365-376, 1994. 
LUNNEY, J.; ETTINGER, S.J. Cardiac arrhythmias. In: ETTINGER, S.J.; FELDMAN, E.C. (Eds). Textbook of Veterinary Internal Medicine: Diseases of the dog and cat. 4.ed. Philadelphia: W.B. Saunders Company, 1995. p.959-995.

MORAES, A.N.; DYSON, D.H.; O'GRADY, M.R. et al. Plasma concentrations and cardiovascular influence of lidocaine infusions during isoflurane anesthesia in healthy dogs and dogs with subaortic stenosis. Vet. Surg., v.27, p.486-497, 1998.

MUGELLI, A. Amiodarone: farmacologia clinica. Ita. Heart J., v.2, p.10S-16S, 2001.

NODA, Y.; HASHIMOTO, K. Development of a halothane-adrenaline arrhythmia model using in vivo guinea pigs. J. Pharmacol. Sci., v.95, p.234239, 2004.

OLIVEIRA, P.F.; DIAS, D.A.; SILVA, V.I. et al. Acute effect of amiodarone on cardiovascular reflexes of normotensive and renal hypertensive rats. Braz. J. Med. Biol. Res., v.38, p.967-976, 2005.
PAULA, D.P.; NUNES, N.; NISHIMORI, C.T. et al. Efeitos da infusão contínua de propofol ou etomidato sobre variáveis intracranianas em cães. Arq. Bras. Med. Vet. Zootec., v.62, p.302-308, 2010.

PODRID, P.J. Amiodarone: Reevaluation of an old drug. Ann. Int. Med., v.122, p.689-700, 1995.

ROONEY, R.T.; STOWE, D.F.; MARIJIC, J. et al. Additive depressant effects of amiodarone given with halothane in isolated hearts. Anesth. Analg., v.72, p.474-481, 1991.

SCHRÖETER, U.; ROGERS, J. Cardiovascular pharmacology for anaesthetists. Update Anaesth., v.11, p.2-7, 2000.

TAKADA, K.; SUMIKAWA, K.; KAMIBAYASHI, T. et al. Comparative efficacy of antiarrhythmic agents in preventing halothane-epinephrine arrhythmias in rats. Anesthesiology, v.79, p.563$570,1993$. 